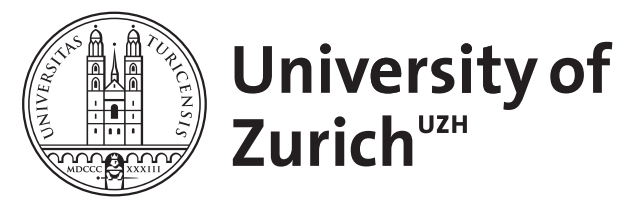

\title{
Happiness and public choice
}

Frey, Bruno S ; Stutzer, Alois

\begin{abstract}
Measuring individual welfare using data on reported subjective well-being has made great progress. It offers a new way of confronting public choice hypotheses with field data, e.g. with respect to partisan preferences on unemployment and inflation or rents in the public bureaucracy. Insights from public choice also help to assess the role of happiness measures in public policy. We emphasize that maximizing aggregate happiness as a social welfare function neglects incentive problems and political institutions while citizens are reduced to metric stations. The goal of happiness research should be to improve the nature of the processes through which individuals can express their preferences.
\end{abstract}

DOI: https://doi.org/10.1007/s11127-010-9681-y

Posted at the Zurich Open Repository and Archive, University of Zurich ZORA URL: https://doi.org/10.5167/uzh-45792

Journal Article

Accepted Version

Originally published at:

Frey, Bruno S; Stutzer, Alois (2010). Happiness and public choice. Public Choice, 144(3-4):557-573.

DOI: https://doi.org/10.1007/s11127-010-9681-y 


\title{
Happiness and Public Choice
}

\author{
Bruno S. Frey* \\ University of Zurich
}

\author{
Alois Stutzer \\ University of Basel
}

and

CREMA - Center for Research in Economics, Management and the Arts, Switzerland

July 12, 2009

\begin{abstract}
Measuring individual welfare using data on reported subjective well-being has made great progress. It offers a new way of confronting public choice hypotheses with field data, e.g. with respect to partisan preferences on unemployment and inflation or rents in the public bureaucracy. Insights from public choice also help to assess the role of happiness measures in public policy. We emphasize that maximizing aggregate happiness as a social welfare function neglects incentive problems and political institutions while citizens are reduced to metric stations. The goal of happiness research should be to improve the nature of the processes through which individuals can express their preferences.
\end{abstract}

Keywords: Economic policy, happiness, life satisfaction, public choice, social welfare JEL Classifications: D60, D70, H11, I31

* Bruno S. Frey: Institute for Empirical Research in Economics, University of Zurich, Winterthurerstrasse 30, CH-8006 Zurich, Switzerland. Phone: +41 (0)44 63437 30, fax: +41 (0)44 63435 99, email: bsfrey@iew.uzh.ch.

Alois Stutzer: Department of Business and Economics, University of Basel, Peter Merian-Weg 6, CH4002 Basel, Switzerland. Phone: +41 (0)61 26733 61, fax: +41 (0)61 26733 40, email: alois.stutzer@unibas.ch.

We are grateful to Peter Bernholz, Jean-Robert Tyran, the participants of the Symposium on (Macro-) Economic Policy and Public Choice at Schloss Wartensee and two anonymous referees for helpful comments. 


\section{Introduction}

The measurement of individual welfare, using data on subjective well-being, has made great progress. This is reflected by a massive increase in the amount of scholarly work on people's subjective well-being ${ }^{1}$ and 'happiness research' in the media. Our paper discusses this development with the background of public choice analysis. We argue that the possibility of adequately measuring individual well-being offers two avenues for productive crossfertilization of research on subjective well-being and public choice. First, direct measures of individual welfare offer a new way of confronting public choice hypotheses with field data. Second, insights from public choice help with assessing the new vision - be it explicit or implicit - of using subjective well-being measures to improve outcomes by using direct policy interventions to maximize some aggregate happiness measure as a social welfare function. Our discussion suggests that the latter is not a worthwhile approach to pursue; there are major objections to this approach from a public choice perspective. We present an alternative view of how the insights gained from happiness research may contribute to policymaking.

Section 2 sets the stage, outlining recent advances in the measurement of subjective wellbeing and naming important advantages of these measures as indicators of individual welfare over the traditional indicators. In section 3, some illustrations are offered on how hypotheses of public choice theory can be confronted with evidence in a novel way using data on subjective well-being. The emphasis is on theories predicting rents in the public bureaucracy. Section 4 assesses happiness maximization from a public choice perspective. We first present the case in favor of happiness maximization. We then discuss it, using fundamental insights from social choice theory and add several incentive distortions induced by the happiness maximization approach. Section 5 outlines an alternative approach on how to use the insights of happiness research for policy from a constitutional point of view. Conclusions are drawn in section 6 .

\footnotetext{
${ }^{1}$ For surveys on the study of happiness in economics, see Oswald (1997), Frey and Stutzer (2002a,b), van Praag and Ferrer-i-Carbonell (2004), Layard (2005), Di Tella and MacCulloch (2006), Dolan et al. (2008) and Frey (2008).
} 


\section{Measuring Individual Welfare}

\subsection{Conceptual Issues}

Happiness research has designed several indicators of subjective well-being, relying on different measurement techniques (for a discussion, see Kahneman et al. 1999; Diener 2005; Kahneman and Krueger 2006): global evaluations of individual life satisfaction, based on representative surveys; the Experience Sampling Method, which collects information on individuals' actual experiences in real time in their natural environments; the Day Reconstruction Method, which asks people to reflect on how satisfied they felt at various times during the day; the U ("unpleasant")-Index, which defines the fraction of time per day that an individual spends in an unpleasant state; and Brain Imaging, which uses functional magnetic resonance imaging (fMRI) to scan individual brain activity for correlates of positive and negative affect.

There is now wide-spread consensus among scholars that these measures capture relevant information about people's well-being. This is indicated by the fact that they correlate well with qualities and behaviors generally associated with happiness. Reliability studies have found that reported subjective well-being is moderately stable and sensitive to changing life circumstances (e.g. Ehrhardt et al. 2000; Schimmack and Oishi 2005). Consistency tests reveal that happy people smile more often during social interactions (Fernández-Dols and Ruiz-Belda 1995); are rated as happy by friends and family members (e.g. Sandvik et al. 1993; Lepper 1998) and by spouses (Costa and McCrae 1988); express positive emotions more frequently, are more optimistic, are more sociable and extravert, and sleep better (Frank 1997, Frey and Stutzer 2002b: 33). Happy people are also less likely to commit suicide (Koivumaa Honkanen et al. 2001; Helliwell 2007).

Obviously, the various measures capture different aspects of individual well-being and thus different concepts of individual welfare. For a measure of reported subjective well-being to serve as a proxy for individual welfare, an important assumption is necessary: The standards underlying people's judgments are those the individual would like to pursue in realizing his or her ideal of the good life. People's judgments about their life can then serve as a proxy for their individual welfare. People are assumed to pursue individual welfare based on some stable evaluation standards. Moreover, the extent to which individual welfare is identified depends on whether the evaluation metric fits people's judgments about their life. 
The normative basis of this approach goes beyond assuming the pursuit of happiness, and also involves choosing the concrete evaluation metric to elicit people's judgments. ${ }^{2}$ Thus, ambiguities remain when selecting the empirical concept in order to measure individual welfare (see Helliwell 2006, Kahneman and Riis 2005 and Kahneman et al. 2004a).

Some people might favor a distant look reflecting on one's life after the fact, while others favor the reasoned ex ante evaluations as their standards. Still others might give priority to how they felt when experiencing the course of life.

Imagine those people who see happiness or high individual welfare as something like the "positive, persistent attitude towards both particular experiences and life experience more generally that a person feels upon repeated reflection" (Kelman 2005, p. 408f). For them, general evaluations of their satisfaction with life as a whole might be an appropriate metric to capture judgments about individual welfare. For those people who equate individual welfare with moment-to-moment affect, individual welfare might be best measured by such approaches as the experience sampling method (Scollon et al. 2003) or the day reconstruction method (Kahneman et al. 2004a). When looking for an empirical tool to collect information about people's judgments, it is thus important to reveal the concrete metric.

Most of the empirical work undertaken so far on happiness research in economics has been based on representative, large-scale sampling of individual global evaluations of life satisfaction. The great advantage of this measurement approach is its good performance compared to its cost, as well as its availability for a large number of countries and time periods. Thus, for example, the surveys on life satisfaction contained in the World Values Survey today cover 80 countries, and represent over 80 percent of the world's population over 4 periods of time. The Gallup World Poll even covers 132 countries and is nationally representative for individuals of 15 years of age and older (see Deaton 2008). For many tasks, self-reported measures of life satisfaction have proved to perform satisfactorily, especially for the issues economists are mostly interested in, namely the influence of economic factors on well-being. So far, we consider it the best empirical approximation to the concept of individual welfare used in economic theory that is widely available. In contrast, Experience Sampling and Brain Imaging are more costly and difficult to apply on a large scale. The Day

\footnotetext{
${ }^{2}$ An excellent account of the ambiguities of welfare in the context of economics and hedonic psychology is provided in Kelman (2005).
} 
Reconstruction Method and the U-Index are new and, so far, have only been used empirically on an experimental basis.

\subsection{Advantages of Subjective Well-Being Indicators of Individual Welfare}

Focusing on reported subjective well-being rather than on individual income or Gross National Product per capita (or another measure of economic activity) as an indicator of individuals' welfare has several important advantages over the traditional indicators. As they have been well documented (see, e.g., Frey and Stutzer 2002a, chapter 2), it is sufficient to make brief comments on three major aspects.

1. Measures of subjective well-being include non-material aspects of human well-being, such as the influence of social relations, autonomy, and self-determination. These are excluded, or inadequately included, in the traditional national accounts, and therewith in GNP. Aggregate happiness measures also go far beyond existing extensions of GNP (for a recent survey, see Michalos 2005), such as the "Measure of Economic Welfare" (Nordhaus and Tobin 1972), "Economic Aspects of Welfare" (Zolatas 1981), "Index of Sustainable Economic Welfare" (Daly and Cobb 1989) or "Human Development Index" (United Nations Development Programme 2005). These indicators exhibit a markedly different development over time than happiness indicators (see, e.g., Blanchflower and Oswald 2005, Leigh and Wolfers 2006).

2. Measures of happiness consider outcome aspects of components already included in GNP via input measures. This holds, in particular, for the vast area of government activity (measured in GNP by the costs of material and labor). It is also directly relevant for (public) health and educational expenditures. "Social Indicators" (e.g. the "Index of Social Progress" by Estes 1988) mostly measure the input side, such as the number of hospital beds and doctors, or the number of class-rooms and teachers.

3. Measures of happiness look at subjectively evaluated outcomes in line with the basic methodological approach of economics. In contrast, the capabilities approach and the "Human Development Index" of the United Nations look at objectively observable functionings (Sen 1985; 1999; Nussbaum 2000).

4. Measures of happiness are able to capture both outcome and procedural utility (this will be discussed in section 4.3). 


\section{Confronting Public Choice Theories with Evidence}

Recent developments in research on subjective well-being in principle allow us to directly analyze the effects of government behavior on (proxy measures of) individual welfare. This offers a new way of assessing phenomena like the rise of the regulatory state (e.g. Glaeser and Shleifer 2003). It becomes possible to empirically explore whether different sets of regulations can be better explained by theories of optimal regulations or by public choice theories, for instance, on lobbying by special interest groups. Many public choice hypotheses predict that government activity tends towards redistribution favoring special interests, and tends to disregard measures improving the overall allocation of private and public resources. These hypotheses can be "directly" challenged with evidence. Based on a proxy measure for individual welfare, "net" effects of different institutions and policies for groups of people can be assessed.

The study of reported subjective well-being also allows us to derive information about voters' preferences in a new way, and to analyze basic assumptions of public choice models. For example, it is possible to explore whether left- and right-wing voters care differently about unemployment and inflation as underlying partisan business cycle models.

\subsection{Partisan Preferences Over Inflation and Unemployment}

Two basic interrelationships in politico-economic models about the interaction between policy makers and voters involve the macro economic measures of unemployment and inflation. On the one hand, voters are hypothesized to make the incumbent government responsible for the state of the economy and support it if unemployment and inflation are low, but vote for the opposition if the economic record of the government is bad. This mechanism has been analyzed in a number of empirical studies on popularity and election functions (see, e.g., Nannestad and Paldam 1994, Feld and Kirchgaessner 2000). On the other hand, in reaction to the economic voting of the citizens, politicians are hypothesized to influence economic performance in order to be reelected. This mechanism is at the core of research on political business cycles (see, e.g., Frey 1997).

The underlying presumption in both relationships is that voters' welfare is affected by the state of the economy (or at least that unemployment and inflation are signals about the quality of policy makers that ultimately determine people's well-being). Moreover, competing models of political business cycles either assume opportunistic parties that simply want to please the median voter with their (macro) economic policy in order to secure reelection (e.g. 
Nordhaus 1975), or start from the presumption that parties pursue an ideology and only serve their clientele if reelection is tight (e.g. Frey and Schneider 1978). The latter models assume that left- and right-wing voters are differently affected by economic performance in a systematic way.

These core assumptions are difficult to study based on observed voting behavior alone. However, information about people's subjective well-being allows us to assess these assumptions directly. It is found that unemployment first reduces the individual well-being of those personally affected. Being unemployed has psychic costs over and above the potential drop in the material living standard (for a review, see Frey and Stutzer 2002, chapter 5). Moreover, high unemployment rates also have non-negligible effects on people who are not personally affected by unemployment. Based on survey data from population samples of European Union member countries between 1975 and 1992, Di Tella et al. (2003) show that aggregate unemployment decreases average reported life satisfaction, even if personal unemployment is kept constant. The cumulative costs of unemployment are substantial. According to their estimation, the average person in the working population would have to be compensated with approximately $\$ 200$ to offset the loss in life satisfaction caused by a typical U.S.-size recession (that is, a recession that entails a 1.5 percentage point increase in the unemployment rate). A related study uses individual panel data for West Germany between 1984 and 2004, and exploits fluctuations in regional unemployment rates that range from around 4 percent to almost 20 percent (Luechinger et al. 2008b). It is found that regional unemployment substantially reduces workers' reported life satisfaction, whereby people working in the private sector are more affected by general economic shocks than people working in the public sector. When regional unemployment rises from the lowest amount (Baden-Wuerttemberg) to the highest amount (West Berlin in 2003) in the sample, the life satisfaction of employees in the private sector is reduced by 0.56 points (on a scale between 0 and 10). In comparison, the negative effect on public sector employees is about a third lower than for private sector employees. Interestingly, for public servants, no negative correlation whatsoever is found between regional unemployment and reported life satisfaction. We are not aware of politico-economic models that take into account the differential exposure of voters to (macro) economic shocks.

Inflation is the second important macro economic variable assumed to affect the welfare of voters. Based on the study by Di Tella et al. (2003) mentioned above, an increase in the inflation rate by one percentage point - say from the mean rate of 8 to 9 percent per year - is 
calculated to reduce average happiness by 0.01 "units" of satisfaction, i.e. from an average level in the sample of 3.02 to 3.01. (Average satisfaction is calculated from a cardinal interpretation of the 4-item scale that attributes "not at all satisfied" a value of 1, "not very satisfied" a value of 2 etc.) Correspondingly, an increase in the inflation rate by 5 percentage points (which is historically quite likely) reduces subjective well-being by 5 percentage points. This is a substantial effect. It means that 5 percent of the population is shifted downwards from one life satisfaction category to the next lower one, e.g. from being "not very satisfied" to "not at all satisfied".

In order to discriminate between models of political business cycles that are either based on opportunistic policy makers (following Nordhaus 1975) or on policy makers with partisan motivation (following Hibbs 1977), the above evidence is not sufficient. Tests need to be done to show whether left- and right-wing voters are differently affected by (macro) economic shocks. In a follow-up study, Di Tella and MacCulloch (2005) analyze whether differential effects are present in their sample of ten European countries between 1975 and 2002. In the basic estimation, it is found that the probability of left-wing individuals reporting high life satisfaction falls by 13.4 percentage points (from $75.1 \%$ to $61.7 \%$ ) if the rate of unemployment increases by ten percentage points. For right-wing individuals, the respective effect is smaller, namely 5.6 percentage points. A reverse order for the magnitude of the effect of inflation on life satisfaction is found. Left-wing individuals are estimated to report a 2.9 percentage points lower probability of high life satisfaction if the price level were to increase by $10 \%$, while the respective estimate for right-wing individuals is -7.2 percentage points. The empirical findings thus support the underlying assumption of partisan models of political business cycles.

\subsection{Government Activity}

Theories in public choice help us to understand and analyze why and to what extent government activity is not in line with citizens' preferences. Rather than assuming an omniscient and benevolent government, informational shortcomings and private interests of legislators and executives are taken into account. There are, for example, a number of public choice hypotheses on why government size is "too big" according to citizens' preferences. These theories emphasize the role of interest groups, the bureaucracy, fiscal illusion or the common pool problems in the cabinet in the growth of government (see, e.g., Mueller 2003). There are, however, also public choice considerations that there is "too little" government 
activity according to the preferences of the population, e.g. if public expenditure (in particular transfers) is kept to a minimum by the ruling elite.

There are a variety of ways in which deviations of public policy from the preferences of the population can be indirectly traced and empirically studied. Disappointment with government activity might be reflected in lower tax morale and tax evasion (e.g. Torgler 2007), retreat into the shadow economy (e.g. Enste and Schneider 2002) or even migration (Devereux and Weisbrod 2006).

With proxy measures of individual welfare, it is in principal possible to directly study which people are positively or negatively affected by a particular government activity. The concrete empirical identification is, of course, a big challenge and faces all the well-known obstacles. A promising approach to empirically explore public choice hypotheses is to formulate them in a comparative institutional framework. Specific government institutions are then related to reports of people's subjective well-being. This allows us, for example, to provide evidence on the consequences of direct versus representative democracy (Frey and Stutzer 2000), proportional versus majoritarian electoral systems, or different degrees of local autonomy (Frey and Stutzer 2000, Bjørnskov et al. 2008). Government outcomes, such as the level of expenditure or taxation, can be directly correlated with subjective well-being in order to identify whether government activity is in line with people's preferences. According to many public choice theories, "big government" disregards people's preferences. However, a large government sector might be closer to citizens' preferred level of government activity exactly in those countries where people experience low subjective well-being, e.g. due to military, environmental or economic adversities. Identifying deviations from people's preferences thus faces major problems. Nevertheless, two findings are worth mentioning. An aggregate crosssection analysis for 74 countries shows a negative partial correlation between government consumption and reported life satisfaction (Bjørnskov et al. 2007). In contrast, a study based on repeated cross-section data for ten European OECD countries between 1975 and 1992 finds a positive, but not statistically significant, relationship between government consumption as a percentage of GDP and life satisfaction (taking into account year and country dummies as well as country specific time trends) (Di Tella and MacCulloch 2005). More specific analyses will be necessary to interpret these findings and to put the various public choice hypotheses on government activity to the test. 


\subsection{Bureaucratic Rents}

A specific group affected by government activity is public sector employees, whereby the monopoly position of the public bureaucracy in providing public services generates rents for them. In contrast to a model of benevolent bureaucracy, a public choice view predicts that bureaucrats will acquire those rents and protect them against dissipation.

In order to understand the checks and balances that restrict the rent-seeking of government sector employees, direct measures of rents are desirable. A rent is understood as the utility premium of a worker in the government sector compared to an equally qualified worker in the private sector. Those rents can consist, for example, of wage differentials, monetary fringe benefits, non-monetary job amenities, and, in certain cases, the possibility of extracting bribes. Traditional approaches, based on wage differentials, either cannot capture all those benefits, or are not applicable, because they start from a competitive equilibrium where no rents exist. Job queues potentially capture total compensation, but proxy the rent only for the marginal position. Furthermore, if government jobs are allocated by cronyism, job queues provide no information on bureaucratic rents. Setting reported bureaucratic corruption equal to rents is not appropriate either, because it is not clear whether corruption leads to extra benefits for public employees, e.g. because there is the possibility of rent dissipation.

Luechinger et al. (2008a) propose a direct measure to capture the rents involved in the government sector: the difference in reported subjective well-being between public bureaucrats and people working in the private sector of a country. If bureaucrats report higher life satisfaction, this differential is interpreted as a utility premium, or simply a rent. ${ }^{3}$ Employees in the government sector are taken to benefit from a higher relative advantage or higher rents in countries where there is a larger positive gap in reported life satisfaction,

\footnotetext{
${ }^{3}$ This interpretation of relative life satisfaction differentials in single countries has to be taken with caution as people self-select into jobs given their preferences (e.g., for a less competitive and an economically more secure environment or for a job that is useful to society) and the institutional restrictions. This self-selection might lead to systematic biases. For example, better educated people are more likely to join the public administration in many countries. To the extent that they are more satisfied with life in general, they contribute to a positive raw differential in subjective well-being even though there might be no rent. In order to reduce any bias in the average effect of working in the public bureaucracy on life satisfaction, an instrumental variable approach would be necessary. However, the instrumental variable approach has proven to be very difficult to apply in the determination of public sector specific wage premiums (Gregory and Borland 1999, p. 3599). We thus resolve to control for differences in observed individual characteristics (like the level of education), as well as unobserved individual characteristics that are correlated with the former. This procedure is expected to reduce the bias in calculated differentials.
} 
ceteris paribus. In contrast to previous approaches for measuring rents in the government sector, this approach has the advantage of measuring the total net utility differential between people working in the public and private sector. The proxy measure can be used to analyze the conditions determining the rents in public bureaucracy. It can be related to political and institutional factors that are argued to facilitate rent extraction, as well as to institutional constraints that are proposed as effective controls, guaranteeing efficiency in the government sector.

In an exploratory study, the approach is applied to data on the life satisfaction of government and private sector employees from 21 European and 17 Latin American countries, based on the European Social Survey and the Latino Barometer respectively (Luechinger et al. 2008a). For each country, the relative well-being differential of an average worker is calculated when employed by the government rather than privately. This approach enables country specific response behavior to be taken into account. A large variation in the life satisfaction of government employees, relative to private employees, is found, ranging from a well-being premium for the former of plus 5 percent to a disadvantage of minus 3 percent. ${ }^{4}$ Relative advantages in life satisfaction in the public bureaucracy do not simply reflect differences in economic development. Rather, taking the level of per capita income into account, the proxy for rents in the public bureaucracy is higher when price controls and administrative obstacles hamper internal competition. Rents are also higher when regulatory trade barriers weaken external competition. In contrast, rents are lower in countries with an affordable independent judicial system and a long democratic track record. It is also shown that there is a sizeable positive correlation between the degree of corruption and the satisfaction gap in a country. The fact that rents positively correlate with corruption shows that the benefits acquired through corruption are neither completely dissipated nor do they compensate for potentially lower regular salaries in the government sector.

\footnotetext{
${ }^{4}$ While a negative differential looks peculiar at first sight, it could be explained by efficiency wages in the private sector. However, we consider two other arguments important to set the differentials in perspective. First, the restriction of the sample to working respondents leads to lower bound estimates of bureaucratic rents for two reasons: (i) former government sector employees usually enjoy exceptionally generous retirement provisions, and (ii) public officials are often protected from dismissal by special statutes. Second, more important than any bias in the general level of the life satisfaction differential would be distortions that affect the ranking of countries with regard to rents in the public bureaucracy. Such distortions would hamper the analysis of the institutional determinants of rents. It is found that the variation of the differentials across countries is robust to the control for selection based on observable characteristics.
} 
These illustrations demonstrate that data on subjective well-being as proxy measures for individual welfare can be analyzed in a new way in order to confront public choice theories with evidence.

\section{Assessing the Maximization of Happiness from a Public Choice Perspective}

\subsection{Arguments in Favor of Happiness Maximization}

The ordinalist revolution in economics, on which classical micro-economics is firmly based, takes it for granted that individual welfare can only be measured in an ordinal, but not in a cardinal way, and that it makes no sense to make interpersonal comparisons of utility. These are exactly the fundamental assumptions where the countermovement of happiness research sets in. Both cardinality and interpersonal comparability may be less of a problem on a practical level than on a theoretical level. ${ }^{5}$ For many applications, milder assumptions suffice. An important example is the valuation of public goods and public bads, based on the life satisfaction approach (see, e.g., Frey et al. 2009, van Praag and Baarsma 2004). Life satisfaction scores are reported on an ordinal scale. Using adequate statistical techniques, like ordered probit or ordered logit, the ordinal information is, however, sufficient to calculate a compensating surplus. Moreover, interpersonal comparability at the level of the individual is not a necessary condition for valuing public goods in the life satisfaction approach. It suffices if individual specific response frames do not systematically vary between different groups exposed to different levels of the public good, either across space or over time. ${ }^{6}$

If the accumulated evidence is judged sufficient, in the sense that it allows for the cardinal measurement and interpersonal comparison of happiness, then it may be argued that one or more social welfare functions exist which can be used to derive policies to be pursued by democratic governments. One specific social welfare function is the unweighted sum of individual cardinal welfare or happiness. This function could be considered 'democratic' in the sense of attributing equal weight to each person. In contrast, the prices relevant for assessing the value of goods entering GNP are largely determined by the preferences of

\footnotetext{
${ }^{5}$ Interestingly enough, psychologists (who are very particular about measurements) seem to be more comfortable when comparing indicators of feelings or utility across individuals (Kahneman et al. 2004b: 432).

${ }^{6}$ There are, of course, the standard problems of identification and the issue of hedonic adaptation that remain when valuing public goods based on the life satisfaction approach.
} 
people with high purchasing power. The preferences of individuals without any income to spend are disregarded.

These steps towards aggregate happiness as a proxy measure for social welfare would fulfill an old dream in economics. Maximizing social welfare as the ultimate goal of economic policy dates back to Bentham (1789) and later to Edgeworth (1881), and was introduced into modern economics by Tinbergen (1956) and Theil (1964). This dream is closely linked with the attempt to turn economics into a natural science comparable to physics. Consistent with this view, Edgeworth uses the title "Mathematical Psychics" (1881) for his book.

In the recent literature, the vision of aggregate happiness as a guideline for policy is well described by Layard in his influential book on "Happiness" (2005):

“(...), there are many major choices where rules provide little guidance. There are public choices like how to treat criminals, or how to solve traffic problems. Simple appeals to principles of freedom or loving-kindness will help little here. (...) The answer can only be found from overarching objectives of maximizing human happiness" (p. 124, emphasis added)

The progress made in measuring happiness also spurs traditional welfare economics on in other ways (see, e.g., $\mathrm{Ng} \mathrm{2003).} \mathrm{In} \mathrm{particular,} \mathrm{it} \mathrm{enables} \mathrm{optimal} \mathrm{policies} \mathrm{to} \mathrm{be} \mathrm{derived}$ numerically in evaluation exercises for government policy.

These developments seemingly support the idea of social welfare maximization, but we nevertheless argue in the following sections that, for a number of reasons, the presumed "socially optimal" values for the various determinants of happiness should not, and will not be used as policy goals to be pursued by democratic governments. In order to avoid any misunderstandings, we certainly do not argue that GNP should be maximized instead of happiness. Rather, we favor a different approach in order to use the valuable insights gained from happiness research.

\subsection{Social Choice Objections to Social Welfare Maximization}

Classical welfare economics, which was initially due to, and strongly influenced by, Robbins (1932) and Hicks and Allen (1934), has for a long time raised fundamental arguments against using the concept of aggregate social welfare in contrast to individual welfare. The two most important, and partially interconnected (see Sen 1970), objections to the concept of aggregate social welfare are (1) the impossibility of cardinal measurement and interpersonal comparisons of individual welfare, and (2) the impossibility theorem relating to aggregate or social welfare. 
Based on the arguments and the evidence presented above, it may be concluded that, while the objections from classical welfare economics must be taken seriously, the existing state of research suggests that, for many purposes, reported subjective well-being is a satisfactory empirical approximation to individual welfare.

However, the problem of aggregating individual preferences to a social welfare function under non-dictatorial conditions remains fundamental. Since Arrow (1951), it has been widely accepted that, given a number of "reasonable" conditions, no social welfare function exists that generally ranks individual orderings of outcomes (e.g. different distributions of wellbeing scores) consistently, except a dictatorship. This impossibility result spawned a huge amount of literature (called 'Social Choice'), analyzing its robustness to modifications of the assumptions. Theorem after theorem demonstrated that almost all changes in the axiomatic structure left the dictatorial result unchanged (see e.g. Sen 1970, 1995, Slesnick 1998). The conclusion has been drawn that "there is no way we can use empirical observations on their own to produce an ethically satisfactory cardinalization, let alone an ethically satisfactory social welfare ordering" (Hammond 1991: 220-21). Empirical observations are not sufficient to produce an acceptable social welfare function in a democracy. It is one of the essential points of our argument that additional aspects need to be considered. Thus, measuring individual welfare in terms of happiness is unable to solve aspects crucial for democratic economic policy.

\subsection{Objections from Political Economics to the Maximization of Aggregate Happiness}

The social welfare maximization approach disregards, and tries to substitute for, existing political institutions and processes. This is the "benevolent dictator" view castigated in Constitutional Political Economy (Buchanan and Tullock 1962, Frey 1983, Brennan and Buchanan 1986, Mueller 1996, 2003 and Vanberg 2005). It applies to all kinds of efforts to derive a "socially optimal" policy from the above, i.e. by maximizing an aggregate goal function. In a democracy, there are constitutionally designed rules and institutions allowing citizens to reveal their preferences, and to provide politicians (the government) with an incentive to actualize them. As such, the maximization of a social welfare function is an intellectual exercise. Even if the government were to pay attention to the results, it has limited incentive to follow up on them.

\section{Citizens as metric stations}


The social welfare maximizing approach, based on empirically estimated happiness functions, disregards the institutions on which democracy is based. Citizens are reduced to "metric stations'. They are forced into a state of passivity, which tends to increase their alienation from the state. In this respect, a happiness maximization approach is inimical to democracy. It disregards the interaction between citizens and politicians, the interest representation by organized groups and the concomitant information and learning processes.

The latter argument refers to the fundamental direct interrelation between the approach applied to collective choices in a society and individual well-being. People have preferences for processes over and above outcomes. They gain well-being from living and acting under institutionalized processes, as they contribute to a positive sense of self, addressing innate needs of autonomy, relatedness and competence. We call this contribution to individual wellbeing 'procedural utility'. In the economy, individuals have been shown to enjoy procedural utility in their capacity as consumers or income earners; in the polity and society, as citizens subjected to different political and societal procedures; in organizations, as employees confronted with different organizational procedures; and in law, as litigants (for an introductory survey, see Frey et al. 2004, and for an application to democracy, see Frey and Stutzer 2005, Olken 2008). If people are reduced to "metric stations", they experience a significant loss in autonomy, and therefore reduced (procedural) well-being, when dealing with public affairs.

Happiness research also fails to provide a rule about the scope and limitations of government intervention in the private sphere. Should the government be allowed to prohibit the consumption of alcohol if this were to raise the population's happiness in the long run, or should this be left to the discretion of individuals (based on the results of happiness research)? And even more importantly: To what extent should the government be allowed to change the preferences of its citizens? Many current interventions might affect people's well-being in the future due to a change in preferences. Consider two extreme cases. Suppose that the government could adopt a policy of making people humble by reducing their material aspirations initially so that they are more appreciative of material benefits afterwards. Or, suppose that the government could raise a National Happiness Indicator by inducing people to take a "happiness pill". Should such policies be accepted? This question cannot be answered within the happiness maximization calculus, but must be decided at a more fundamental level. A feasible and theoretically consistent approach is to resort to the constitutional level, where people make such fundamental decisions behind the veil of uncertainty (see section 5). 
Probably the most fundamental issue is whether happiness is the ultimate goal to be maximized. Other valid goals, for instance, may be loyalty, responsibility, self-esteem, freedom or personal development. It is easy to imagine that a single mother with several children does not consider her emotional well-being to be of primary importance in her life. Responsibility may carry much more weight. Whether happiness is the ultimate goal of individuals, or whether it is only one of several goals, has been a controversial issue in philosophy for centuries.

\section{Playing the system}

So far, we have assumed that the decision to maximize social welfare in terms of aggregate (measured) happiness does not have any influence on the measurement of subjective wellbeing. This assumption is highly debatable. Indeed, the political use of aggregate happiness would certainly induce strategic interactions between government and individuals. Two kinds of distortions need to be taken into account.

Once aggregate happiness has become politically relevant, the government, public bureaucracy and various interest groups have an incentive to manipulate it. This has proved to be true for GNP and for other economic indicators declared to be goals of government activity. As the unemployment rate has become a politically important indicator, governments have started to influence it in order to paint a better picture of the state of the labor market than is actually the case. Thus, for instance, people who have been unemployed for a long time are no longer defined as being in the workforce so as to lower the official unemployment rate. It is also a well-known fact that the way of measuring budget deficits has been manipulated by some European countries when the rules for entering the European Monetary Union required that budget deficits did not exceed three percent of GDP and that public debt did not exceed sixty percent of GDP. Many EU member countries (most notably Greece and Italy) resorted to accounting tricks or "creative accounting" in order to meet these requirements, though in reality they clearly violated them (see, e.g., Forte 2001; von Hagen and Wolff 2004). Such distortions of indicators were so widespread that it was observed that "[...] the determining factor for achieving membership of the planned European Monetary Union (EMU) seems to rely on widespread use of public-sector creative accounting

\footnotetext{
${ }^{7}$ Creative accounting does not violate the law, but it is clearly against the spirit of the law and accounting standards. It uses the rules, the flexibility provided by them and the omissions within them, in order to make financial statements which look different from what is intended by the rule (Jameson 1988).
} 
measures" (Dafflon and Rossi 1999: 59-60). In the rare case that a government is unable to manipulate a particular indicator to its benefit, it has an incentive to create new indicators. This is easily possible in the case of happiness. As has been pointed out in the second section, a variety of indicators may capture individual well-being. Governments and pressure groups will choose those indicators most beneficial to their respective interests, or will create new ones better suited to their purposes (like, e.g., the "Happy Planet Index" (Marks et al. 2006)).

A second systematic distortion stems from respondents' incentives to misrepresent their wellbeing. When individuals become aware that the happiness level they report influences the behavior of political actors, they have an incentive to misrepresent it. They can "play the system".

The two systematic distortions discussed represent a basic phenomenon, which even applies to the natural sciences. The Heisenberg Uncertainty Principle states that the observation of a system fundamentally disturbs it. In the social sciences, both the observation and public reporting can change the observed behavior of the people involved. This reaction is related to Goodhart's Law and the Lucas Critique (see Chrystal and Mizen 2003). ${ }^{8}$ Goodhart's Law (1975) states that any observed statistical relationship - such as the happiness function - will tend to collapse once pressure is placed upon it for control purposes. The Lucas Critique (1976) refers more specifically to econometric modeling: a different policy making behavior (such as using an aggregate happiness indicator) influences the expectations of private agents and this changes behavior in a rational-expectations model.

\section{A Constitutional View on Happiness Research}

The discussion so far has endeavored to show that the maximization of aggregate happiness as a social welfare function is a doubtful approach for several reasons. First, governments are not composed of purely benevolent politicians wanting to make the population as happy as possible. Rather, the personal interests of politicians are also a factor. Second, the essential elements of democratic governance are disregarded: democracy consists of interaction between politicians and citizens on many different levels, structured by the constitution and not simply recording the reported well-being of the citizens. Third, the government has an incentive to manipulate the happiness indicators and to create new ones to suit their goals.

\footnotetext{
${ }^{8}$ An important application is to the relationship between inflation and unemployment as captured in the Philips Curve. The functional relationship might cease to exist once monetary authorities attempt to exploit it.
} 
Fourth, the individuals have an incentive to misrepresent their happiness levels strategically in order to influence government policy in their favor. Fifth, some might also claim that problems of cardinality and interpersonal comparability can never be fully overcome.

We argue that happiness research should not aim at constructing a social welfare function at all, but that the insights provided by happiness research should be used in a different way. Our vision rests on the fundamental presumption that the quality of the political process is a key factor to people's happiness and that the legitimacy of political action finally rests on the voluntary agreement of the citizens involved. Individual sovereignty should not be reduced to self-reports on well-being. It should include choices on how to best pursue happiness, both individually and collectively. The claim is not for 'naïve' consumer or citizen sovereignty, which assumes optimal behavior. People, with their bounded rationality and bounded willpower, are sometimes aware of their own limitations (and sometimes only aware of the limitations of their fellow citizens).

Accordingly, at the collective level, the political process should be institutionally structured so that people's common interests become the principal driving force. Economic policy must help to establish those fundamental institutions, which make politicians and pubic bureaucrats most responsive to people's common interests (dominating behind a veil of ignorance) and which finally lead to the best possible fulfillment of individual preferences. As argued above, happiness is not necessarily people's ultimate goal. It may even be that people see some virtue in unhappiness if they reckon that discontent is the only way to overcome social ills.

Happiness research has two different practical uses for policy: (1) It helps to identify which institutions enable individuals to best meet their preferences, and which therefore contribute most to their personal happiness; (2) It provides important informational inputs for the political process.

(1) Happiness research provides insights on how, and to what extent, institutions have systematic effects on indicators of individual well-being (see also section 3.2). The emphasis is on institutions rather than specific policy interventions. To give an example, happiness policy should focus on the relationship between the fiscal constitution of a jurisdiction and people's subjective well-being rather than on the optimal tax scheme in terms of happiness. The range of institutions under study includes self-binding mechanisms, social norms, private and public law (i.e. the rules of the game), as well as 
constitutional conditions on how to choose rules. The latter, for example, involves the possibility of direct democratic decision making (Frey and Stutzer 2000).

(2) The results gained from happiness research should be taken as informational inputs into the political process. These inputs have yet to prove themselves in political competition, in citizens' discourse, and also in the discourse between citizens and politicians. Happiness research has already produced many insights, which can be introduced into the political discussion process. They include policy issues like, for example, the effect of mandatory retirement and mandatory schooling on happiness (Charles 2002; Oreopoulos 2005); the consequences of social work norms, birth control rights and other women's rights on women's well-being (Lalive and Stutzer 2004; Pezzini 2005); the impact of tobacco taxes on smokers' well-being (Gruber and Mullainathan 2005); or the relation between working time regulations and people's subjective well-being (Alesina et al. 2005). A competent overview of selected findings, with policy relevance, is provided by Diener and Seligman (2004).

The proposed constitutional vision takes into account that there is a demand for happiness research in the current politico-economic process. For example, parties in competition will want to learn about voters' preferences from data on reported subjective well-being. This demand for analyses might include evaluations of specific policy issues as well as grand policy schemes. Or, the public administration involved in valuing public goods will use the life satisfaction approach (for an application, see, e.g. Frey et al. 2009) in order to get complementary information for cost-benefit analyses.

\section{Conclusion}

Happiness research and public choice can both benefit from taking each other's key insights into account. Improvements in the measurement of individual welfare allow us to confront public choice hypotheses in a new way with empirical evidence. This has been illustrated for basic assumptions on the partisan model of political business cycles, theories of government size and rents in the public bureaucracy.

The huge progress in the measurement of individual welfare makes it tempting to pursue the old dream of maximizing aggregate happiness as a social welfare function. Improvements in individual welfare are claimed to be directly measurable, and politics is seen as following advice and implementing it with suitable interventions in the political process. 
Based on public choice analysis, we argue that the appropriate approach is not to maximize aggregate happiness directly by seeking to improve outcomes through direct interventions. Rather, we see the role of happiness research as seeking to improve the nature of the political processes. Individuals should have more opportunity of advancing what constitutes their idea of the good life, both individually and collectively. They should be made aware that different issues require different measures and indicators of well-being. Happiness research should remain open to constructing a number of different indicators, reflecting well-being according to different aspects of life. Plurality is a necessary consequence of the procedural view outlined. This is in stark contrast to the maximization approach requiring one single objective. From a constitutional standpoint, we conclude that people are best served with comparative institutional analyses on subjective well-being. 


\section{References}

Alesina, Alberto, Edward Glaeser and Bruce Sacerdote (2005). Work and Leisure in the United States and Europe: Why So Different? In: Mark Gertler and Kenneth Rogoff (eds). NBER Macroeconomics Annual 2005. Cambridge, MA: MIT Press: 1-64.

Arrow, Kenneth J. (1951). Social Choice and Individual Values. New York: John Wiley \& Sons.

Bentham, Jeremy (1789). An Introduction to the Principles of Morals and Legislation. Oxford: Clarendon Press.

Bjørnskov, Christian, Axel Dreher and Justina A. V. Fischer (2007). The Bigger the Better? Evidence of the Effect of Government Size on Life Satisfaction around the World. Public Choice 130(3-4): 267-292.

Bjørnskov, Christian, Axel Dreher and Justina A. V. Fischer (2008). On Decentralization and Life Satisfaction. Economic Letters 99(1): 147-151.

Blanchflower, David G. and Andrew J. Oswald (2005). Happiness and the Human Development Index: The Paradox of Australia. Australian Economic Review 38(3): 307-318.

Brennan, Geoffrey and James M. Buchanan (1986). The Reason of Rules: Constitutional Political Economy. Cambridge, MA: Cambridge University Press.

Buchanan, James M. and Gordon Tullock (1962). The Calculus of Consent. Logical Foundations of Constitutional Democracy. Ann Arbor: University of Michigan Press.

Charles, Kerwin Kofi (2002). Is Retirement Depressing? Labor Force Inactivity and Psychological Well-Being in Later Life. NBER Working Paper No. 9033, Cambridge, MA.

Chrystal, K. Alec and Paul D. Mizen (2003). Goodhart's Law: Its Origins, Meaning and Implications for Monetary Policy. In: Paul D. Mizen (ed.). Central Banking, Monetary Theory and Practice: Essays in Honour of Charles Goodhart, vol. 1. Cheltenham, U.K. and Northampton, MA, USA: Edward Elgar: 221-243.

Costa, Paul T. and Robert R. McCrae (1988). Personality in Adulthood: A Six-Year Longitudinal Study of Self-Reports and Spouse Ratings on the Neo Personality Inventory. Journal of Personality and Social Psychology 54(5): 853-863.

Dafflon, Bernard and Sergio Rossi (1999). Public Accounting Fudges Towards Emu: A First Empirical Survey and Some Public Choice Considerations. Public Choice 101(1-2): 59-84.

Daly, Herman E. and John B. Cobb (1989). For the Common Good: Redirecting the Economy toward Community, the Environment, and a Sustainable Future. London: Green Print.

Deaton, Angus (2008). Income, Health, and Well-Being around the World: Evidence from the Gallup World Poll. Journal of Economic Perspectives 22(2): 53-72.

Devereux, Paul J. and Burton A. Weisbrod (2006). Does 'Satisfaction' with Local Public Services Affect Complaints (Voice) and Geographic Mobility (Exit)? Public Finance Review 34(2): 123-147.

Di Tella, Rafael and Robert J. MacCulloch (2005). Partisan Social Happiness. Review of Economic Studies 72(2): 367-393.

Di Tella, Rafael and Robert J. MacCulloch (2006). Some Uses of Happiness Data in Economics. Journal of Economic Perspectives 20(1): 25-46.

Di Tella, Rafael, Robert J. MacCulloch and Andrew J. Oswald (2003). The Macroeconomics of Happiness. Review of Economics and Statistics 85(4): 809-827.

Diener, Ed (2005). Guidelines for National Indicators of Subjective Well-Being and Ill-Being. Mimeo, University of Illinois at Urbana Champaign.

Diener, Ed and Martin E. P. Seligman (2004). Beyond Money: Toward an Economy of WellBeing. Psychological Science in the Public Interest 5(1): 1-31. 
Dolan, Paul, Tessa Peasgood and Mathew White (2008). Do We Really Know What Makes Us Happy? A Review of the Economic Literature on the Factors Associated with Subjective Well-Being. Journal of Economic Psychology 29(1): 94-122.

Edgeworth, Francis Y. (1881). Mathematical Psychics: An Essay on the Application of Mathematics to the Moral Sciences. London, UK: Kegan Paul.

Ehrhardt, Joop J., Willem E. Saris and Ruut Veenhoven (2000). Stability of Life-Satisfaction over Time: Analysis of Change in Ranks in a National Population. Journal of Happiness Studies 1(2): 177-205.

Enste, Dominik and Friedrich Schneider (2002). The Shadow Economy: An International Survey. Cambridge, UK: Cambridge University Press.

Estes, Richard (1988). Trends in World Social Development: The Social Progress of Nations, 1970-1987. New York: Praeger.

Feld, Lars P. and Gebhard Kirchgässner (2000). Official and Hidden Unemployment and the Popularity of the Government: An Econometric Analysis of the Kohl Government. Electoral Studies 19(2-3): 333-347.

Fernández-Dols, José-Miguel and María-Angeles Ruiz-Belda (1995). Are Smiles a Sign of Happiness? Gold Medal Winners at the Olympic Games. Journal of Personality and Social Psychology 69(6): 1113-1119.

Forte, Francesco (2001). The Maastricht "Excessive Deficit" Rules and Creative Accounting. In: Ram Mudambi, Pietro Navarra and Giuseppe Sobbrio (eds). Rules and Reason. Cambridge, UK: Cambridge University Press.

Frank, Robert H. (1997). The Frame of Reference as a Public Good. Economic Journal 107 (445): 1832-1847.

Frey, Bruno S. (1983). Democratic Economic Policy: A Theoretical Introduction. Oxford: Robertson.

Frey, Bruno S. (ed.) (1997). Political Business Cycles. Cheltenham, UK: Edward Elgar.

Frey, Bruno S. (2008). Happiness: A Revolution in Economics. Cambridge, MA: MIT Press.

Frey, Bruno S., Matthias Benz and Alois Stutzer (2004). Introducing Procedural Utility: Not Only What, But Also How Matters. Journal of Institutional and Theoretical Economics 160(3): 377-401.

Frey, Bruno S., Simon Luechinger and Alois Stutzer (2009). The Life Satisfaction Approach to Valuing Public Goods: The Case of Terrorism. Forthcoming in Public Choice.

Frey, Bruno S. and Friedrich Schneider (1978). An Empirical Study of Politico-Economic Interaction in the United States. Review of Economics and Statistics 60(2): 174-183.

Frey, Bruno S. and Alois Stutzer (2000). Happiness, Economy and Institutions. Economic Journal 110(466): 918-938.

Frey, Bruno S. and Alois Stutzer (2002a). Happiness and Economics: How the Economy and Institutions Affect Well-Being. Princeton and Oxford: Princeton University Press.

Frey, Bruno S. and Alois Stutzer (2002b). What Can Economists Learn from Happiness Research? Journal of Economic Literature 40(2): 402-435.

Frey, Bruno S. and Alois Stutzer (2005). Beyond Outcomes: Measuring Procedural Utility. Oxford Economic Papers 57(1): 90-111.

Glaeser, Edward L. and Andrei Shleifer (2003). The Rise of the Regulatory State. Journal of Economic Literature 41(2): 401-425.

Goodhart, Charles A. E. (1975). Money, Information and Uncertainty. London: Macmillan.

Gregory, Robert G. and Jeff Borland (1999). Recent Developments in Public Sector Labor Markets. In: Orley Ashenfelter and David Card (eds). Handbook of Labor Economics, vol. 3C. Amsterdam: Elsevier: 3573-3630.

Gruber, Jonathan H. and Sendhil Mullainathan (2005). Do Cigarette Taxes Make Smokers Happier? Advances in Economic Analysis and Policy 5(1): 1-43. 
Hammond, Peter J. (1991). Interpersonal Comparisons of Utility: Why and How They Are and Should Be Made. In: J. Elster and J. E. Roemer (eds.). Interpersonal Comparisons of Well-Being. Cambridge: Cambridge University Press: 200-254.

Helliwell, John F. (2006). Well-Being, Social Capital and Public Policy: What's New? Economic Journal 116(510): C34-C45.

Helliwell, John F. (2007). Well-Being and Social Capital: Does Suicide Pose a Puzzle? Social Indicators Research 81(3): 455-496.

Hibbs, Douglas A. (1977). Political Parties and Macroeconomic Policy. American Political Science Review 71(4): 1467-1487.

Hicks, John R. and Roy G. D. Allen (1934). A Reconsideration of the Theory of Value, I. Economica 1: 52-75.

Jameson, Michael (1988). Practical Guide to Creative Accounting. London: Kogan Page.

Kahneman, Daniel and Alan B. Krueger (2006). Developments in the Measurement of Subjective Well-Being. Journal of Economic Perspectives 20(1): 3-24.

Kahneman, Daniel, Ed Diener and Norbert Schwarz (eds) (1999). Well-Being: The Foundations of Hedonic Psychology. New York, NY: Russell Sage Foundation.

Kahneman, Daniel, Alan B. Krueger, David A. Schkade, Norbert Schwarz and Arthur A. Stone (2004a). A Survey Method for Characterizing Daily Life Experience: The Day Reconstruction Method. Science 306(5702): 1776-1780.

Kahneman, Daniel, Alan B. Krueger, David A. Schkade, Norbert Schwarz and Arthur A. Stone (2004b). Toward National Well-Being Accounts. American Economic Review 94(2): 429-434.

Kahneman, Daniel and Jason Riis (2005). Living, and Thinking About It: Two Perspectives on Life. In: Felicia A. Huppert, Nick Baylis and Barry Keverne (eds.). The Science of Well Being. Oxford: Oxford University Press.

Kelman, Mark (2005). Hedonic Psychology and the Ambiguities of "Welfare". Philosophy and Public Affairs 33(4): 391-412.

Koivumaa Honkanen, Heli, Risto Honkanen, Heimo Viinamaki, Kauko Heikkila, Jaakko Kaprio and Markku Koskenvuo (2001). Life Satisfaction and Suicide: A 20-Year Follow-up Study. American Journal of Psychiatry 158(3): 433-439.

Lalive, Rafael and Alois Stutzer (2004). Approval of Equal Rights and Gender Differences in Well-Being. IEW Working Paper No. 194, University of Zurich.

Layard, Richard (2005). Happiness: Lessons from a New Science. New York: Penguin.

Leigh, Andrew and Justin Wolfers (2006). Happiness and the Human Development Index: Australia Is Not a Paradox. Australian Economic Review 39(2): 176-184.

Lepper, Heidi S. (1998). Use of Other-Reports to Validate Subjective Well-Being Measures. Social Indicators Research 44(3): 367-379.

Lucas, Robert E. (1976). Econometric Policy Evaluation: A Critique. In: Karl Brunner and Allan H. Meltzer (eds.). The Phillips Curve and Labor Markets. Carnegie-Rochester Conference Series on Public Policy, Vol. 1. New York: North-Holland: 19-46.

Luechinger, Simon, Stephan Meier and Alois Stutzer (2008a). Bureaucratic Rents and Life Satisfaction. Forthcoming in the Journal of Law, Economics, and Organization 24(2).

Luechinger, Simon, Stephan Meier and Alois Stutzer (2008b). Why Does Unemployment Hurt the Employed? Evidence from the Life Satisfaction Gap between the Public and the Private Sector. WWZ Discussion Paper No. 03/08, University of Basel.

Marks, Nic, Andrew Simms, Sam Thompson and Saamah Abdallah (2006). The Happy Planet Index: An Index of Human Well-Being and Environmental Impact. London: New Economics Foundation.

Michalos, Alex C. (ed.) (2005). Citation Classics from Social Indicators Research. The Most Cited Articles. Dordrecht: Springer. 
Mueller, Dennis C. (1996). Constitutional Democracy. New York: Oxford University Press.

Mueller, Dennis C. (2003). Public Choice III. Cambridge, New York and Melbourne: Cambridge University Press.

Nannestad, Peter and Martin Paldam (1994). The VP-Function - A Survey of the Literature on Vote and Popularity Functions after 25 Years. Public Choice 79(3-4): 213-245.

$\mathrm{Ng}$, Yew-Kwang (2003). From Preference to Happiness: Towards a More Complete Welfare Economics. Social Choice and Welfare 20(2): 307-350.

Nordhaus, William (1965). The Political Business Cycle. Review of Economic Studies 42(2): 169-190.

Nordhaus, William and James Tobin (1972). Is Growth Obsolete? NBER General Series No. 96. New York: Columbia University Press.

Nussbaum, Martha C. (2000). Women and Human Development: The Capabilities Approach. Cambridge: Cambridge University Press.

Olken, Benjamin (2008). Direct Democracy and Local Public Goods: Evidence from a Field Experiment in Indonesia. NBER Working Paper No. 14123.

Oreopoulos, Philip (2005). Do Dropouts Drop out Too Soon? Wealth, Health, and Happiness from Compulsory Schooling. Mimeo, Department of Economics, University of Toronto.

Oswald, Andrew J. (1997). Happiness and Economic Performance. Economic Journal 107 (445): 1815-1831.

Pezzini, Silvia (2005). The Effect of Women's Rights on Women's Welfare: Evidence from a Natural Experiment. Economic Journal 115(502): C208-C227.

Robbins, Lionel C. (1932). An Essay on the Nature and Significance of Economic Science. London: Macmillan. Selections reprinted in Daniel M. Hausman (ed.). (1984) The Philosophy of Economics: An Anthology. New York: Cambridge University Press.

Sandvik, Ed, Ed Diener and Larry Seidlitz (1993). Subjective Well-Being: The Convergence and Stability of Self-Report and Non-Self-Report Measures. Journal of Personality 61(3): 317-342.

Schimmack, Ulrich and Shigehiro Oishi (2005). The Influence of Chronically and Temporarily Accessible Information on Life Satisfaction Judgments. Journal of Personality and Social Psychology 89(3): 395-406.

Scollon, Christie Napa, Chu Kim Prieto and Ed Diener (2003). Experience Sampling: Promises and Pitfalls, Strengths and Weaknesses. Journal of Happiness Studies 4(1): 5-34.

Sen, Amartya K. (1970). Collective Choice and Social Welfare. San Francisco: Holden-Day.

Sen, Amartya K. (1985). Commodities and Capabilities. Amsterdam: North Holland.

Sen, Amartya K. (1995). Rationality and Social Choice. American Economic Review 85(1): $1-24$.

Sen, Amartya K. (1999). Development as Freedom. New York: Alfred Knopf.

Slesnick, Daniel T. (1998). Empirical Approaches to the Measurement of Welfare. Journal of Economic Literature 36(4): 2108-2165.

Theil, Henri (1964). Optimal Decision Rules for Government and Industry. Amsterdam: North Holland.

Tinbergen, Jan (1956). Economic Policy: Principles and Design. Amsterdam: North Holland.

Torgler, Benno (2007). Tax Compliance and Tax Morale: A Theoretical and Empirical Analysis. Cheltenham, UK: Edward Elgar.

United Nations Development Programme (2005). Human Development Report 2005. New York: United Nations Development Programme.

Vanberg, Viktor J. (2005). Market and State: The Perspective of Constitutional Political Economy. Journal of Institutional Economics 1(1): 23-49. 
van Praag, Bernard M. S. and Barbara E. Baarsma (2004). Using Happiness Surveys to Value Intangibles: The Case of Airport Noise. Economic Journal 115(500): 224-246.

van Praag, Bernard M. S. and Ada Ferrer-i-Carbonell (2004). Happiness Quantified - a Satisfaction Calculus Approach. Oxford: Oxford University Press.

von Hagen, Jürgen and Guntram B. Wolff (2004). What Do Deficits Tell Us About Debts?: Empirical Evidence on Creative Accounting with Fiscal Rules in the EU. Series 1: Studies of the Economic Research Centre. Discussion Paper No. 38, Deutsche Bundesbank.

Zolatas, Xenophon (1981). Economic Growth and Declining Social Welfare. Athens: Bank of Greece. 